\title{
"IT'S A THING TO MEASURE THINGS": LEARNING ABOUT MEASUREMENT IN EARLY CHILDHOOD TEACHER EDUCATION IN PORTUGAL
}

\author{
M. Figueiredo ${ }^{1}$, H. Gomes ${ }^{2}$, I. Aires de Matos ${ }^{1}$ \\ ${ }^{1}$ Polytechnic of Viseu, School of Education and CI\&DEI (PORTUGAL) \\ ${ }^{2}$ Polytechnic of Viseu, School of Education, and CIDMA, University of Aveiro (PORTUGAL)
}

\begin{abstract}
A Lesson Study about length measurement in Early Childhood Education was developed collaboratively by students in initial Early Childhood Teacher Education as part of their practicum. The students from the Master's Degree in Early Childhood and Primary Education developed a "Lesson" for three settings and data was collected so it could be discussed in terms of: a) children's knowledge about measurement revealed in actions and discourse, and b) features of the planning that were aligned with ECE Pedagogy. The planning was based on listening to children as well as on valuing play as a means to understand children's knowledge and experiences. We present results from the data recorded in the reports prepared by the students: participant observation records of the 125 children during the activities. Children focused primarily on measuring as finding a result and measuring as an action associated with jobs or professionals. Most children mentioned home as the context where the tools were familiar. The diversity of experiences highlights the importance of homeschool communication for mathematics and the relevance of play as an arena for children's complex understandings to be shared. Strict didactical sequences for measuring were perceived as disregarding that complexity.
\end{abstract}

Keywords: Early Childhood Education, Teacher Education, Lesson Study, Mathematics, Measurement.

\section{INTRODUCTION}

A Lesson Study (Lewis, 2002) about length measurement in Early Childhood Education was developed collaboratively by students in initial Early Childhood Teacher Education as part of their practicum. Although Lesson Studies are commonly used for in-service teacher education, there are studies that consider it for initial teacher education [1]-[5]. An essential dimension in the education of future teachers is the development of their ability to learn from pedagogical practice, and Lesson Studies have the potential to serve as a context for this process. Particularly in Mathematics Education, there has been a growth of studies [6].

The 12 students from the Master's Degree in Early Childhood and Primary Education were organized to work together in a Lesson Study structure, based in two cycles of planning-testing-reflecting the research lesson. The organization in pairs for the practicum meant that six groups of student teachers were placed in Early Childhood Education (ECE) settings and, therefore, worked daily with up to 25 children from 3 to 6 years old. In total, there were six different settings and close to 120 children.

In this paper, we present results from the data recorded in the reports prepared by the students: participant observation records of the 120 children (corresponding to 6 groups) during the activities.

First, we introduce Lesson Studies and some topics about measurement in Early Childhood Education. Following that, the cycles that were experienced by the student teachers is analysed. Finally, a summary of the children's actions is discussed.

\section{LESSON STUDIES}

Lesson study is a direct translation for the Japanese term jugyokenkyu, which is composed of two words: jugyo, which means lesson, and kenkyu, which means study or research [7]. Hence, lesson study consists of the study or examination of a teaching practice through a well-defined process that involves discussing lessons that were first planned and observed together. "These lessons are called kenkyujugyo, which is simply a reversal of the term jugyokenkyu and thus literally means study or research lessons, or more specifically lessons that are the object of one's study" [7, p. 7]. This process 
usually follows a set of steps included in cycles which are aimed at a research goal that the teachers have chosen to work on (e.g., understanding children's conceptions of measurement):

- Step 1: Collaboratively Planning the Study Lesson, with great detail and in collaboration.

- Step 2: Seeing the Study Lesson in Action through its implementation by one of the teachers while the other teachers observe.

- Step 3: Discussing the Study Lesson in group by sharing what was observed.

(ends cycle 1)

- Step 4: Revising the Lesson (Optional) based on what was discussed.

- Step 5: Teaching the New Version of the Lesson (Optional), by a second teacher again with observers.

- Step 6: Sharing Reflections About the (New) Version of the Lesson, again as a group that shares observations, comments, and suggestions.

(ends cycle 2)

In a general way, in lesson study, a group of teachers work together, beginning by identifying difficulties that students usually have in a given topic or issue related to a curriculum aim. Then, they prepare a lesson that may provide an important contribution to overcome those difficulties. [8].

Lesson Studies are herald as contributing to teachers professional development but also to teachers' professional knowledge [2]. This holds true to the ones involved in each study but also to others that have access to the refined lesson plans and records of students' reactions, difficulties, and results. The positive discourse about lesson study shouldn't hide the demanding nature of the process that its dissemination across different countries has shown: planning and conducting lesson study may become problematic in many situations [8].

\section{MEASUREMENT IN EARLY CHILDHOOD EDUCATION}

Early childhood education (ECE) in Portugal focuses on the ages of 3 to 6 and is called preschool education. Before the age of three, there is mainly socio-educational provision, whereas preschool education is the first stage of the education system. The Ministry of Education is responsible for ensuring the pedagogical quality of teaching in all preschool education institutions (public and private). Since 1997, there are Curricular Guidelines for Preschool Education but not a programme. The Guidelines were updated in 2016.

The teachers' intervention or pedagogy is enacted through the organization of the learning environment and the planning of activities. The learning environment should foster rich play which is highly valued in the 2016 version of the Guidelines. When organizing the learning environment and planning educational activities, the teacher should create opportunities for learning in all content areas. The content areas serve as references for curriculum planning and evaluation [9]. Mathematics is included as a domain in "Expression and Communication", one of three content areas.

In terms of content and learning expectations, the 2016 Guidelines present four blocks for mathematics: numbers and operations; data organization and analysis; geometry and measurement; and interest and curiosity in mathematics. In the measurement content area, the focus is on identifying measurable attributes in objects. This perspective was introduced in 2008 when a booklet about geometry and measurement (Mendes \& Delgado, 2008), alongside one about numbers and data, was published by the Ministry of Education, to support teachers' curricular and pedagogical work. The trajectory and methodology suggested are very similar, and inspired by, the TAL project [10]. The Guidelines lay out a process that starts with identifying measurable attributes - both in play and through teacher-led activities - and then being able to choose a measurement unit (natural or standard) to compare objects to, translating that comparison into a number. This should begin with direct comparisons between objects and move to non-standard measurement units (pencils, steps, etc.) and, finally, to standard units (in activities that are meaningful for the children, like cooking). The need to measure in real situations is highlighted to promote the understanding of the sense of measurement in daily life, as well as the need for standard measures. It is also suggested that those situations involve different physical quantities (length, weight, capacity, volume, time and temperature). 
Having play as the basis of the pedagogical intervention has allowed to observe how children react to the more complex standard measurement tools without direct intervention of the adult. In [11], children playing with a taylor's measuring tape showed they had previous experience with the tool, knowing what it was, it's purpose and how to use it, to a limit. The complexity of their experiences and knowledge is an indicator of how the learning trajectory shouldn't be mistaken for a guide for teaching (activities or/and play).

\section{A LESSON STUDY IN INITIAL IN EARLY CHILDHOOD TEACHER EDUCATION}

The 12 students from the Master's Degree in Early Childhood and Primary Education were organized into three groups. Each group included four students that were placed in two different Early Childhood Education (ECE) settings and, therefore, worked daily with up to 25 children from 3 to 6 years old. In total, there were six different settings and close to 120 children.

As part of the Lesson Study process, in the first cycle, all groups planned together. The same "research lesson" was developed for the six ECE settings. The first round of implementation happened in three contexts and prepared data collection on: a) children's knowledge about measurement revealed in actions and discourse, and b) features of the planning that were aligned with ECE Pedagogy.

The second cycle of planning, implementation, in three different settings, and reflection was developed after the analysis and discussion of cycle 1 . After the second cycle, reports were prepared by each group.

The planning was based on listening to children as well as on valuing play as a means to understand children's knowledge and experiences. These principles are coherent with the perspective on Mathematics and its Didactics reflected in the Portuguese Curricular Guidelines for Early Childhood Education [9] and offer children opportunities for meaningful learning [12]. Methodologically, the Guidelines take as a starting point the interests, experiences, and daily life of the children. The teacher should find ways to observe and reflect on those, and then offer diverse and challenging experiences and help children to reflect and discuss them to support the construction of mathematical ideas.

The process included several participants, besides the student teachers. It was supported by the Professors from Didactics of Mathematics and Early Childhood Education Pedagogy. For the discussion of the lesson plan and the implementation, the cooperating ECE teachers that are in the settings where the practicum is developed were actively engaged. For the end of cycle discussions, professors from other content areas (Language, Arts, Physical Education, Natural Sciences, Social Sciences and ICT) were present and contributed to amplify the analysis beyond mathematics learning. The children participated in the two phases of implementation.

The observations were focused on the children's reactions to the measurement tools that were made available, both in terms of manipulation and speech - what was done and said. The observers were also prepared to record time, as a long stare can be very meaningful in ECE settings. Mobile cameras are current in ECE settings so those were used to record some moments. In table 1 a detailed description of each phase is presented, showing how the focus shifted throughout the process. 
Table 1. Adapted Lesson Study process

\begin{tabular}{|c|c|c|c|}
\hline Phase & Participants & Focus & Process \\
\hline Preparation & $\begin{array}{l}\text { Student teachers in } \\
\text { a large group (12) } \\
\text { Professors of } \\
\text { Mathematics and } \\
\text { ECE }\end{array}$ & $\begin{array}{l}\text { Knowledge of content about } \\
\text { measurement } \\
\text { Didactic principles about teaching } \\
\text { measurement in ECE } \\
\text { Children's conceptions about } \\
\text { measurement (previous studies) }\end{array}$ & $\begin{array}{l}\text { Analysis and discussion of } \\
\text { documents and studies }\end{array}$ \\
\hline Planning & $\begin{array}{l}\text { Student teachers in } \\
\text { a large group (12) } \\
\text { Professors of } \\
\text { Mathematics and } \\
\text { ECE } \\
\text { Cooperating ECE } \\
\text { Teachers }\end{array}$ & $\begin{array}{l}\text { Conception of lesson plan/proposal } \\
\text { for ECE } \\
\text { Selection of teaching materials } \\
\text { related to measurement } \\
\text { Preparation of } \\
\text { records/documentation and of the } \\
\text { research questions }\end{array}$ & $\begin{array}{l}\text { Analysis of existing proposals } \\
\text { and of the learning trajectory } \\
\text { Analysis of existing teaching } \\
\text { materials } \\
\text { Discussion between groups } \\
\text { and with professors and ECE } \\
\text { teachers }\end{array}$ \\
\hline $\begin{array}{l}\text { Implementation and } \\
\text { documentation } 1\end{array}$ & $\begin{array}{l}\text { Student teachers in } \\
\text { groups } \\
\text { Cooperating ECE } \\
\text { Teachers } \\
\text { Children }\end{array}$ & $\begin{array}{l}\text { Implementation in } 3 \text { ECE settings ( } 1 \\
\text { hour }+1 \text { hour) } \\
\text { Documentation through participant } \\
\text { observation }\end{array}$ & $\begin{array}{l}\text { One element of each group } \\
\text { observed while the other } \\
\text { implemented the lesson }\end{array}$ \\
\hline $\begin{array}{l}\text { Discussion and } \\
\text { reflection } 1\end{array}$ & $\begin{array}{l}\text { Student teachers in } \\
\text { small groups ( } 3 \\
\text { groups of } 4) \\
\text { Professors of } \\
\text { Mathematics and } \\
\text { ECE and of other } \\
\text { content areas }\end{array}$ & $\begin{array}{l}\text { Sharing and systematization of data } \\
\text { from the observations } \\
\text { Analysis of the ideas expressed by } \\
\text { the children (orally and by actions) } \\
\text { Analysis of the lesson plan and of } \\
\text { the two implementations } \\
\text { Identifying changes to the lesson } \\
\text { plan } \\
\text { Definition of research questions }\end{array}$ & $\begin{array}{l}\text { Presentation by each small } \\
\text { group of a synthesis of the } \\
\text { work that was developed, } \\
\text { focusing on the children's } \\
\text { actions } \\
\text { Large group discussion } \\
\text { Reports }\end{array}$ \\
\hline $\begin{array}{l}\text { Implementation and } \\
\text { documentation } 2\end{array}$ & $\begin{array}{l}\text { Student teachers in } \\
\text { groups } \\
\text { Cooperating ECE } \\
\text { Teachers } \\
\text { Children }\end{array}$ & $\begin{array}{l}\text { Changes to the lesson plan } \\
\text { Implementation in } 3 \text { ECE settings (1 } \\
\text { hour }+1 \text { hour) } \\
\text { Documentation through participant } \\
\text { observation }\end{array}$ & $\begin{array}{l}\text { One element of each group } \\
\text { observed while the other } \\
\text { implemented the lesson }\end{array}$ \\
\hline $\begin{array}{l}\text { Discussion and } \\
\text { reflection } 2\end{array}$ & $\begin{array}{l}\text { Student teachers in } \\
\text { small groups ( } 3 \\
\text { groups of } 4) \\
\text { Professors of } \\
\text { Mathematics and } \\
\text { ECE and of other } \\
\text { content areas }\end{array}$ & $\begin{array}{l}\text { Sharing and systematization of data } \\
\text { from the observations } \\
\text { Analysis of the ideas expressed by } \\
\text { the children (orally and by actions) } \\
\text { Analysis of the lesson plan and of } \\
\text { the two implementations } \\
\text { Selection of data for the research } \\
\text { questions }\end{array}$ & $\begin{array}{l}\text { Presentation by each small } \\
\text { group of a synthesis of the } \\
\text { work that was developed, } \\
\text { focusing on the children's } \\
\text { actions } \\
\text { Large group discussion } \\
\text { Reports }\end{array}$ \\
\hline
\end{tabular}

\section{RESULTS AND DISCUSSION}

The planning started with making available length measurement tools so children could play freely and then, after a large group conversation, it was suggested that children use the tools in role-playing situations connected to real-life situations.

Children focused primarily on measuring as finding a result and measuring as an action associated with jobs or professionals. Most children mentioned home as the context where the tools were familiar. The diversity of experiences highlights the importance of home-school communication for mathematics [13] and the relevance of play as an arena for children's complex understandings to be shared. Strict didactical sequences for measuring were perceived as disregarding that complexity. 


\section{ACKNOWLEDGEMENTS}

This work was funded by National Funds through the FCT -Foundation for Science and Technology, I.P., within the scope of the projectRef ${ }^{a}$ UIDB/05507/2020. Furthermore we would like to thank the Centre for Studies in Education and Innovation (CI\&DEI) and the Polytechni of Viseu for their support.

\section{REFERENCES}

[1] T. Conceição, M. Baptista, and J. P. Ponte, 'Lesson study as a trigger for preservice physics and chemistry teachers' learning about inquiry tasks and classroom communication', Conceição $T$ Baptista M Ponte J P 2019 Lesson Study Trigger Preserv. Phys. Chem. Teach. Learn. Inq. Tasks Classr. Commun. Int. J. Lesson Learn. Stud. 81 79-96, vol. 8, no. 1, pp. 79-96, 2019.

[2] T. Conceição, M. Baptista, and J. P. Ponte, 'Lesson study in initial teacher education to stimulate pedagogical content knowledge on the speed of sound. Acta Scientiae, 22(2), 29-47.', Acta Sci., vol. 22, no. 2, pp. 29-47, 2020.

[3] A. M. Leavy and M. Hourigan, 'Using Lesson Study to support knowledge development in initial teacher education: Insights from early number classrooms', Teach. Teach. Educ., vol. 57, pp. 161-175, 2016.

[4] R. Bjuland and R. Mosvold, 'Lesson study in teacher education: Learning from a challenging case', Teach. Teach. Educ., vol. 52, pp. 83-90, 2015.

[5] B. Cavadas and N. Branco, 'Estudo de aula interdisciplinar na formação de futuros professores de Matemática e Ciências Naturais do $2 .^{\circ}$ ciclo do ensino básico [Interdisciplinary lesson study in teacher education of mathematics and science preservice teachers of elementary school]', Quadrante, vol. 29, no. 1, 2020.

[6] R. Huang, A. Takahashi, and J. P. Ponte, 'Theory and practice of lesson study in mathematics around the world', in Theory and practice of lesson study in mathematics, R. Huang, A. Takahashi, and J. P. Ponte, Eds. Springer, 2019, pp. 3-12.

[7] M. Yoshida and C. Fernandez, Lesson Study. A Japanese Approach to Improving Mathematics Teaching and Learning. Lawrence Erlbaum Associates, Inc, 2004.

[8] J. P. da Ponte, J. P. da Ponte, M. Quaresma, J. Mata-Pereira, and M. Baptista, 'Fitting Lesson Study to the Portuguese Context', in Mathematics Lesson Study Around the World, M. Quaresma, C. Winsløw, S. Clivaz, A. Ní Shúilleabháin, and A. Takahashi, Eds. Cham: Springer International Publishing, 2018, pp. 87-103.

[9] Ministry of Education, Curricular Guidelines for Early Childhood Education. Lisbon: Ministerio da Educação, 2016.

[10] M. Van den Heuvel-Panhuizen and K. Buys, Young children learn measurement and geometry (TAL Project). Utrecht: Freudenthal Institute, Utrecht University, The Netherlands, 2005.

[11] M. P. Figueiredo et al., 'It's a lot of work": A tailor's measuring tape in the dollhouse', in Mathematics in Early Childhood Research, Reflexive Practice and Innovative Pedagogy, O. Thiel, E. Severina, and B. Perry, Eds. Abingdon: Routledge, 2020, pp. 79-94.

[12] O. Thiel, E. Severina, and B. Perry, Eds., Mathematics in Early Childhood Research, Reflexive Practice and Innovative Pedagogy. Abingdon: Routledge, 2020.

[13] A. J. Bishop, 'Can Values Awareness Help Teachers and Parents Transition Preschool Learners into Mathematics Learning?', in Mathematics Education in the Early Years, T. Meaney, O. Helenius, M. L. Johansson, T. Lange, and A. Wernberg, Eds. Cham: Springer International Publishing, 2016, pp. 43-56. 